\title{
Effects of a specific blend of essential oils on apparent nutrient digestion, rumen fermentation and rumen microbial populations in sheep fed a 50:50 alfalfa hay:concentrate diet
}

\author{
N. Khateri ${ }^{1}$, 0. Azizi $^{1{ }^{*}}{ }^{\text {, and H. Jahani-Azizabadi }}{ }^{1}$
}

\begin{abstract}
* Corresponding Author: 0. Azizi Tel: +98-8733660067, Fax: +98-8733620553, E-mail: o.azizi@uok.ac.ir
\end{abstract}

'Department of Animal Science, Faculty of Agriculture, University of Kurdistan, Sanandaj, Kurdistan, P.O. Box: 416 , Iran

Submitted Oct 20, 2015; Revised Dec 1, 2015; Accepted Jan 15, 2016
Objective: An experiment was conducted to investigate the effects of a specific mixture of essential oils (MEO), containing thyme, clove and cinnamon EO, on rumen microbial fermentation, nutrient apparent digestibility and blood metabolites in fistulated sheep.

Methods: Six sheep fitted with ruminal fistulas were used in a repeated measurement design with two 24-d periods to investigate the effect of adding MEO at 0 (control), 0.8 , and $1.6 \mathrm{~mL} / \mathrm{d}$ on apparent nutrient digestibility, rumen fermentation characteristics, rumen microbial population and blood chemical metabolites. Animals were fed with a 50:50 alfalfa hay:concentrate diet.

Results: Ruminal $\mathrm{pH}$, total volatile fatty acids (VFA) concentration, molar proportion of individual VFA, acetate: propionate ratio and methane production were not affected with MEO. Relative to the control, Small peptides plus amino acid nitrogen and large peptides nitrogen concentration in rumen fluid were not affected with MEO supplementation; while, rumen fluid ammonia nitrogen concentration at 0 and $6 \mathrm{~h}$ after morning feeding in sheep fed with $1.6 \mathrm{~mL} / \mathrm{d}$ of MEO was lower $(\mathrm{p}<0.05)$ compared to the control and $0.8 \mathrm{~mL} / \mathrm{d}$ of MEO. At $0 \mathrm{~h}$ after morning feeding, ammonia nitrogen concentration was higher $(\mathrm{p}<0.05)$ in sheep fed $0.8 \mathrm{~mL} / \mathrm{d}$ of MEO relative to $1.6 \mathrm{~mL} / \mathrm{d}$ and control diet. Ruminal protozoa and hyper ammonia producing (HAP) bacteria counts were not affected by addition of MEO in the diet. Relative to the control, no changes were observed in the red and white blood cells, hemoglobin, hematocrit, glucose, beta-hydroxybutyric acid, cholesterol, total protein, albumin, blood urea nitrogen and aspartate aminotransferase and alanine aminotransferase concentration. Apparent total tract digestibility of dry matter, crude proten, organic matter, and neutral detergent fiber were not influenced by MEO supplementation.

Conclusion:The results of the present study suggested that supplementation of MEO may have limited effects on apparent nutrient digestibility, ruminal fermentation and protozoa and HAP bacteria count, blood cells and metabolites.

Keywords: Apparent Digestibility; Essential Oils; Rumen Fermentation; Hyper Ammonia Producing Bacteria; Sheep

\section{INTRODUCTION}

In response to the rising concern about the use of growth promoter antibiotics in animal production systems due to an increase in the probability of antibiotic resistance, the use of growth promoting antibiotics in animal production is banned in most developed countries [1]. Previous studies have shown selective activity of essential oils (EO) against several microorganisms including bacteria [2,3], fungi [4] and phages [5]. One of the candidates in this regard are plant $\mathrm{EO}$ and their extracts that have potential for manipulation of rumen fermentation as alternatives to growth promoter antibiotics [6-8]. The evaluation of EO for antimicrobial, antifungal and 
antioxidant properties has been conducted by humans for centuries in traditional medicine [9]. Following the ban of growth promoting antibiotics in animal nutrition, research on the use of plant extracts and $\mathrm{EO}$ in animal production has developed all over the world. Recently, the effects of many plants $\mathrm{EO}$ on rumen microbial fermentation were investigated. From wide investigation of plant $\mathrm{EO}$, the results from clove, cinnamon and thyme EO were more favorable, due to their valuable effects on rumen fermentation such as decrease in methane emissions and ammonia nitrogen $(\mathrm{N})$ concentration and an increase in propionate to acetate ratio [10-14]. Jahani-Azizabadi et al [14] reported that the addition of Cinnamon, Clove and Thyme EO resulted in a decrease in vitro ruminal ammonia $\mathrm{N}$ concentration and an increase in $\mathrm{pH}$ of medium culture. Synergistic and antagonistic effects between different compounds of EO previously were reported [3]. Therefore, we investigated the effects of some mixtures of $\mathrm{EO}$ which differed in proportions of thyme:cinnamon: clove EO (50:30:20; 30:50:20; 40:40:20, and 33.3:33.3:33.3) on rumen microbial fermentation. Our earlier results showed that the mixture consisted of 50\% thyme, $30 \%$ cinnamon, and $20 \%$ clove $\mathrm{EO}$ at 250 to $500 \mu \mathrm{L} / \mathrm{L}$ resulted in a significant decrease in in vitro crude protein $(\mathrm{CP})$ disappearance, ammonia nitrogen concentration, gas production and an increase in fermentation efficiency, volatile fatty acids concentration and propionate: acetate ratio (unpublished). Therefore, the aim of the present study was to investigate the effects of a specific mixture of $\mathrm{EO}$ (MEO), containing thyme, clove and cinnamon essential oils, on rumen microbial fermentation and nutrient apparent digestibility of a 50:50 forage:concentrate diet and blood metabolites in fistulated sheep.

\section{MATERIALS AND METHODS}

\section{Animals, diets and treatments}

Six sheep (initial live body weigh $34 \pm 2.5 \mathrm{~kg}$ ) fitted with ruminal fistula were used in a repeated measurement design with two 24-d periods ( $7 \mathrm{~d}$ for changing ration, $10 \mathrm{~d}$ for adaptation, and $7 \mathrm{~d}$ for sampling). Sheep were kept in individual metabolic pens $(90 \times 90 \mathrm{~cm})$. Animals were fed with a total mixed ration (TMR) ration contained 50:50 forage:concentrate (Table 1) without supplementation (as control) or supplemented with 0.8 and 1.6 $\mathrm{mL} / \mathrm{d} / \mathrm{h}$ ead of a MEO (50\% thyme, $30 \%$ cinnamon, and $20 \%$ clove essential oils). Thyme, cinnamon and clove EO were provided from MONIN (MONIN company, Bourges, France). Daily MEO for each animal was mixed with a part of daily concentrate then divided into two equal parts and added to ration of each meal. Experimental diets were offered in equal amounts twice daily at 08:00 and 16:00 h. Animals had free access to water at all times.

\section{Ruminal fermentation characteristics}

Forty eight hours before starting sampling, special probes screwed
Table 1. Ingredients and chemical composition of experimental diet

\begin{tabular}{lc}
\hline & Amount $\mathbf{( g / k g )}$ \\
\hline Alfalfa hay & 500 \\
Barley grain & 142.5 \\
Corn grain & 125 \\
Wheat grain & 149 \\
Soybean meal & 63.5 \\
Calcium carbonate & 4 \\
Salt & 3.5 \\
Mineral-vitamin premixe ${ }^{1)}$ & 12.2 \\
Urea & 0.3 \\
Chemical composition & \\
DM (g/kg) & 904 \\
OM (g/kg DM) & 911 \\
CP (g/kg DM) & 167 \\
NDF (g/kg DM) & 330 \\
ADF (g/kg DM) & 209 \\
Ether extract (g/kg DM) & 39 \\
Ash & 89 \\
\hline
\end{tabular}

$\mathrm{DM}$, dry matter; OM, organic matter; $\mathrm{CP}$, crude protein; NDF, neutral detergent fiber; $A D F$, acid detergent fiber.

${ }^{1)}$ Contained (per $\mathrm{kg}$ ) 1,200,000 IU/ $\mathrm{kg}$ of vitamin A, 5,000 IU/kg of vitamin E, 100,000 IU/kg of vitamin $D_{3}, 90 \mathrm{~g} / \mathrm{kg}$ of $\mathrm{Ca}, 55 \mathrm{~g} / \mathrm{kg}$ of $P, 69 \mathrm{~g} / \mathrm{kg}$ of $\mathrm{S}, 75.8 \mathrm{~g} / \mathrm{kg}$ of $\mathrm{Mg}, 33.4 \mathrm{~g} /$ $\mathrm{kg} \mathrm{Mn}, 2.5 \mathrm{~g} / \mathrm{kg}$ of Fe, $1.1 \mathrm{~g} / \mathrm{kg} \mathrm{Cu}, 7.7 \mathrm{~g} / \mathrm{kg} \mathrm{Zn}, 115 \mathrm{mg} / \mathrm{kg} \mathrm{Co}, 100 \mathrm{mg} / \mathrm{kg} \mathrm{Se}, 94 \mathrm{mg} /$ $\mathrm{kg}$ of $\mathrm{I}$.

to a plastic tube and covered with thin socks for collection rumen fluid were placed in the rumen. Four hours after morning feeding on day 18 of each sampling period, rumen fluid was sampled using $50-\mathrm{mL}$ plastic syringe to determine the concentration of total volatile fatty acids (VFA) $(0.375 \mathrm{~mL}$ of orthophosphoric acid and the solution was added to $1.5 \mathrm{~mL}$ rumen fluid). On $\mathrm{d}$ 19 of each sampling period at $0,2,4$, and $6 \mathrm{~h}$ after morning feeding for determining ruminal ammonia $\mathrm{N}$ concentration, a sample of rumen fluid was taken $(5 \mathrm{~mL}$ of $0.2 \mathrm{~N} \mathrm{HCL}$ was added to $5 \mathrm{~mL}$ rumen fluid). Also, $40 \mathrm{~mL}$ of rumen fluid at 2 and $6 \mathrm{~h}$ after morning feeding was taken for determining tangestic acid soluble $\mathrm{N}$ (TAN) and trichloroacetic acid soluble $\mathrm{N}$ (TCAN). Samples frozen at $-20^{\circ} \mathrm{C}$ for later determination of VFA and ammonia nitrogen $(\mathrm{N})$, large peptide (LPepN) and small peptide plus amino acid N (Spep+AAN) concentrations. On d 20, ruminal $\mathrm{pH}$ was measured every 15 minutes to $8 \mathrm{~h}$ after morning feeding (Accumet pH meter, Fisher Scientific, Montreal, Quebec, Canada).

\section{Blood cells and serum metabolites}

On $\mathrm{d} 21$ of each sampling period at $4 \mathrm{~h}$ after morning feeding blood samples were obtained from jugular vein of all sheep into two 10-mL Vacutainer tubes. One of the tubes contained 0.15 $\mathrm{mL}$ 10-percent ethylenediaminetetraacetic acid (EDTA) solution ( $\mathrm{w} / \mathrm{v}$, as anti-clotting) to determine blood cells concentration and other one was without anticoagulation agent for investigation of serum chemical parameters [7]. 
Apparent total tract nutrients digestibility

For measuring apparent total tract nutrients digestibility, during sampling period feed consumption was recorded daily with weighing feed offered to/and refused by sheep. Samples of TMR, feed ingredients, and orts were collected daily and kept frozen. The samples were composited by period, dried at $60^{\circ} \mathrm{C}$ for 48 $\mathrm{h}$, ground through a 1-mm screen and analyzed for dry matter (DM), organic matter (OM), CP, and neutral detergent fiber (NDF). During sampling period, daily feces were weighed, mixed and a representative sample ( $10 \%$ of total feces) was taken and kept frozen. Subsequently samples were thawed, dried at $60^{\circ} \mathrm{C}$ for $48 \mathrm{~h}$, and ground though a 1-mm screen for chemical analysis and analyzed for DM, OM, CP, and NDF concentration.

\section{Microbial counts}

Protozoa and hyper ammonia producing (HAP) bacteria counts were carried out on rumen fluid samples collected $4 \mathrm{~h}$ after morning feeding. For protozoa enumeration, 5-mL of filtered rumen fluid was preserved using 5-mL of 50\% Formalin (18.5\% concentration of formaldehyde) as described by Dehority [15]. Two drops of Brilliant green dye were added to $1 \mathrm{~mL}$ of rumen fluid $(n=2)$ and stored overnight at laboratory temperature. Then, $9 \mathrm{~mL}$ of $30 \%$ glycerol solution was added. Protozoa were enumerated microscopically in a Sedgwick-Rafter counting chamber.

For enumeration of HAP bacteria, ruminal contents were obtained from sheep using ruminal probes at $4 \mathrm{~h}$ after morning feeding, and immediately strained through four layers of cheesecloth into six separate flasks $(200 \mathrm{~mL}, 4$ replicates/treatment). The flasks were closed and allowed to stand for $1 \mathrm{~h}$ at $38.6^{\circ} \mathrm{C}$. Rumen fluid was then collected by suction from the middle of each flask. The ruminal fluid containing bacteria was serially diluted (10-fold increments) in the liquid version of [16] medium plus $15 \mathrm{~g} / \mathrm{L}$ of peptides (Terypticas, Becton Dickinson) and $15 \mathrm{~g} / \mathrm{L}$ of amino acids (Casamino acids, Sigma 22090, St. Louis, MO, USA) as an energy source in the Hungate tubes $[17,18]$. The tubes were incubated at $38.6^{\circ} \mathrm{C}$ for $72 \mathrm{~h}$, and at the end of incubation, HAP bacteria growth was scored (+ or -) by the increase in optical density $(650 \mathrm{~nm})$. The bacteria population size was estimated using most probable number procedure from replicate (3 tubes/dilution) dilutions.

\section{Chemical analyses}

Ash contents of diets and feces were determined by incineration at $550^{\circ} \mathrm{C}$ for overnight, and the $\mathrm{OM}$ content was calculated as the difference between 100 and the percentage of ash [19]. The TCA- and TA-soluble $\mathrm{N}$ were determined as described by Winter et al [20]. A 16-mL sample of filtered rumen fluid was added to $4 \mathrm{~mL}$ of $10 \%$ (wt/vol) sodium tungstate and $4 \mathrm{~mL}$ of $1.07 \mathrm{~N}$ sulfuric acid. After allowing the tubes to stand at $5^{\circ} \mathrm{C}$ for $4 \mathrm{~h}$, they were centrifuged at $9,000 \times \mathrm{g}$ for $15 \mathrm{~min}$. The supernatant was frozen until analyzing for TA soluble N. To determine TCA soluble N, $4 \mathrm{~mL}$ of $50 \%$ (wt/vol) TCA solution was added to 16 $\mathrm{mL}$ of filtered rumen fluid. After $4 \mathrm{~h}$ at $5^{\circ} \mathrm{C}$, tubes were centrifuged at $9,000 \times \mathrm{g}$ for $15 \mathrm{~min}$. The supernatant was frozen until analyzing for TCA soluble N. The results were used to calculate the large peptide $\mathrm{N}(\mathrm{L}-\mathrm{PepN})(\mathrm{LPep}=\mathrm{TCA}$ soluble $\mathrm{N}-\mathrm{TA}$ soluble $\mathrm{N}$ ), and small peptide (SPep) plus amino acid $\mathrm{N}$ (SPep+ AAN = TA soluble $\mathrm{N}-$ ammonia $\mathrm{N}$ ) concentrations [21]. Total $\mathrm{N}$ concentration of TMR, alfalfa hay, concentrate, orts, feces and rumen fluid were determined using Kjeldahl procedure according to standard methods [19]. Crude protein was calculated as Nx 6.25. Neutral detergent fiber (NDF) and acid detergent fiber (ADF) were determined using the method introduced by Van Soest et al [22]. Samples for VFA analysis were prepared as described by Jouany [23]. Briefly, samples were centrifuged $15,000 \times \mathrm{g}$ for $15 \mathrm{~min}$ and the supernatant was analyzed by gas chromatography (GC, Philips Unicam, PU 4410, Amsterdam, Netherlands). Whole blood samples were analyzed for concentrations of white blood cells (WBC), red blood cells (RBC), hematocrit and hemoglobin distribution (Hematology Analyzer, Sysmex KX21, Mississauga, ON, Canada). Serum was recovered for analysis of glucose, total protein, albumin, beta-hydroxybutyric acid (BHBA), Cholesterol, blood urea nitrogen (BUN), alanine aminotransferase (ALT) and aspartate aminotransferase (AST) using the specific kits by Auto analyzer (HITACHI 7070, Japan care Co. City, Japan).

\section{Calculation and statistical analysis}

The methane production was calculated from $\mathrm{CH}_{4}=(1.8$ [acetic acid]-1.1[propionic acid]+1.6[butyric acid]) [24]. All data were analyzed using the PROC MIXED of SAS (version 9.1; SAS Inst., Inc., Cary, NC, USA). Period was considered as a random effect. For the statistical analysis of ruminal fermentation characteristics ( $\mathrm{pH}, \mathrm{NH}_{3}-\mathrm{N}, \mathrm{L}-\mathrm{PepN}$, and S-Pep+AAN), sampling time and sampling timextreatment were added to the model and analyzed using repeated measures of PROC MIXED. The results are reported as the least square means and significance was declared at $\mathrm{p}<0.05$. Linear and quadratic orthogonal contrasts were tested using the CONTRAST statement of SAS (V. 8.2, [25]).

\section{RESULTS AND DISCUSSION}

Rumen fermentation characteristics and microbial counts The addition of MEO did not have significant effects on total VFA concentration, molar proportion of acetate, propionate, butyrate, iso-valric acid and acetate:propionate ratio (A:P) (Table 2 ). This would agree with the results of in vivo studies on sheep $[26,27,7]$ and dairy cows [28,29]. Castillejos et al [30] and Benchaar et al [11] observed an in vitro increase in total VFA concentration and no changes in molar proportion of individual VFA with supplementation of a mixture of EO compounds (CRINA, CRINA RUMINANTS, Heanor, Derbyshire, UK), 
Table 2. Ruminal VFA concentration of sheep fed a 50:50 forage:concentrate diet supplemented or not supplemented with a MEO

\begin{tabular}{|c|c|c|c|c|c|c|c|c|c|}
\hline & \multicolumn{3}{|c|}{ MEO (mL/d) } & \multirow{2}{*}{ SEM } & \multicolumn{3}{|c|}{$\mathrm{p}$-value } & \multicolumn{2}{|c|}{ Contrast } \\
\hline & Control & 0.8 & 1.6 & & Treatment & Period & Treatmentxperiod & Linear & Quadratic \\
\hline $\begin{array}{l}\text { Total VFA (mmol/L) } \\
\text { Individual VFA (mol/100 mol) }\end{array}$ & 112.5 & 102.8 & 115.8 & 29.57 & 0.91 & 0.87 & 0.77 & NS & NS \\
\hline Acetate (A) & 0.54 & 0.54 & 0.56 & 0.018 & 0.59 & 0.46 & 0.99 & NS & NS \\
\hline Propionate (P) & 0.22 & 0.23 & 0.23 & 0.015 & 0.79 & 0.4 & 0.74 & NS & NS \\
\hline Butyrate & 0.21 & 0.21 & 0.19 & 0.023 & 0.50 & 0.8 & 0.35 & NS & NS \\
\hline IsoValerate & 0.01 & 0.009 & 0.01 & 0.002 & 0.27 & 0.25 & 0.19 & NS & NS \\
\hline$A: P$ & 2.45 & 2.35 & 2.43 & 0.03 & 0.94 & 0.39 & 0.87 & NS & NS \\
\hline Methane (mmol) & 0.39 & 0.39 & 0.39 & 0.002 & 0.46 & 0.46 & 0.80 & NS & NS \\
\hline
\end{tabular}

VFA, volatile fatty acids; MEO, mixture of essential oils (50\% thyme, 30\% cinnamon, and 20\% clove); SEM, standard error of mean; NS, non significant; A:P, acetate:propionate ratio .

defined as natural EO compounds that included thymol, eugenol, vanillin and limonen; [4] that contained main secondary compounds such as thyme and eoginul that are the main compounds of thyme and clove essential oils in the MEO used in the present study. However, most of the in vitro $24 \mathrm{~h}$ batch culture studies reported decrease in total VFA concentration [10,30,31] with addition of EO. Castilljios et al [30] reported that thymol at $500 \mathrm{mg} / \mathrm{L}$ in a continuous culture system decreased the substrate fermentability; total VFA concentration and molar proportion of acetate and increased the molar proportion of propionate. Busquet et al [10] observed that the addition of clove bud oil and eugenol at 3,000 $\mathrm{mg} / \mathrm{L}$ in batch culture system resulted in a decrease in total VFA concentration. Inconsistency between the results of in vitro and in vivo studies could be due to the length that rumen microbiota are exposed to EO (e.g. short time exposure in 24 to $48 \mathrm{~h}$ batch culture vs 24 to 48 days in vivo) and microbial adaptation and/or degrading of EO compounds [32]. Cardozo et al [33] and Busquet et al [34] observed that effects of $\mathrm{EO}$ compounds on rumen microbial fermentation in dual flow continuous culture disappeared after $6 \mathrm{~d}$ from start of incubation. Supplementation with MEO had no effect on methane production based molar proportion of acetate, propionate and butyrate. Jahani-Azizabadi et al $[14,35]$ observed a decrease in methane production when thyme, cinnamon and clove essential oils were supplemented at $1 \mu \mathrm{L} / \mathrm{mL}$ or at 70,140 , and $280 \mathrm{ppm}$ in $24 \mathrm{~h}$ batch culture studies.

Minimum, maximum and mean of ruminal $\mathrm{pH}$ were not significantly affected by supplementation with MEO, but were higher for sheep fed diet supplemented with 1.6 mL MEO (Table 3). Lower ruminal $\mathrm{pH} 7 \mathrm{~h}$ after morning feeding in sheep fed with the diet supplemented by $0.8 \mathrm{~mL}$ of MEO (Figure 1) suggested that $\mathrm{MEO}$ could be result in a change in fermentation pattern. Chaves et al [27] observed a decrease in ruminal $\mathrm{pH}$ when lambs were fed with a mixture of EO. On the other hand, Benchaar et al [36] and Yang et al [37] reported no change in dairy cow and beef cattle ruminal $\mathrm{pH}$ when cinnamaldehyde was supplemented to the diet.

Supplementation of the diet with MEO did not have an effect on concentration of S-Pep +AAN and L-PepN in ruminal fluid at 2 and $6 \mathrm{~h}$ after morning feeding (Table 4). The addition of 1.6 $\mathrm{mL} / \mathrm{head}$ of MEO resulted in a linear decrease $(\mathrm{p}<0.05)$ in ammonia $\mathrm{N}$ concentration at 0 and $6 \mathrm{~h}$ after morning feeding (Figure 2). The MEO treatments tended to an increase in the average of S-Pep+AAN concentration ( $p>0.05)$. Therefore, the results of the present study suggested that deamination process was inhibited with addition $1.6 \mathrm{~mL} /$ head of MEO. JahaniAzizabadi et al [14] observed a decrease in ammonia $\mathrm{N}$ concentration when thyme, cinnamon and clove EO were added at dose $1 \mu \mathrm{L} / \mathrm{mL}$ of culture fluid in a $24 \mathrm{~h}$ batch culture study. Benchaar et al $[6,11]$ reported that ammonia $\mathrm{N}$ concentration of ruminal fluid of dairy cows was not affected with addition of 0.75 or $2 \mathrm{~g} / \mathrm{d}$ of a mixture of EO compounds. Chaves et al $[27,7]$ observed no change in rumminal fluid ammonia $\mathrm{N}$ concentration of lambs fed with cinnamaldehyde at 100,200, and $400 \mathrm{mg} / \mathrm{kg}$ of DM. The discrepancy in ammonia $\mathrm{N}$ in response to MEO supplementation between the present study with other in vivo observation may be attributed to different experimental diet, doses of MEO or compounds used and experimental conditions. Assuming a rumen volume of $4 \mathrm{~L}$, the concentration of MEO for sheep consuming 0.8 and $1.6 \mathrm{~mL}$

Table 3. Maximum, minimum, and mean of rumen pH in sheep fed a 50:50 forage:concentrate diet supplemented or not supplemented with a MEO

\begin{tabular}{|c|c|c|c|c|c|c|c|}
\hline \multirow{2}{*}{$\mathrm{pH}$} & \multicolumn{3}{|c|}{ MEO (mL/d) } & \multirow{2}{*}{ SEM } & \multicolumn{3}{|c|}{$p$-value } \\
\hline & Control & 0.8 & 1.6 & & Treatment & Period & Treatmentxperiod \\
\hline Maximum & 6.66 & 6.66 & 6.82 & 0.23 & 0.53 & 0.02 & 0.007 \\
\hline Minimum & 5.8 & 5.85 & 6.02 & 0.23 & 0.53 & 0.02 & 0.007 \\
\hline Mean & 6.14 & 6.06 & 6.29 & 0.23 & 0.53 & 0.02 & 0.007 \\
\hline
\end{tabular}

MEO, mixture of essential oils (50\% thyme, 30\% cinnamon, and 20\% clove); SEM, standard error of mean. 


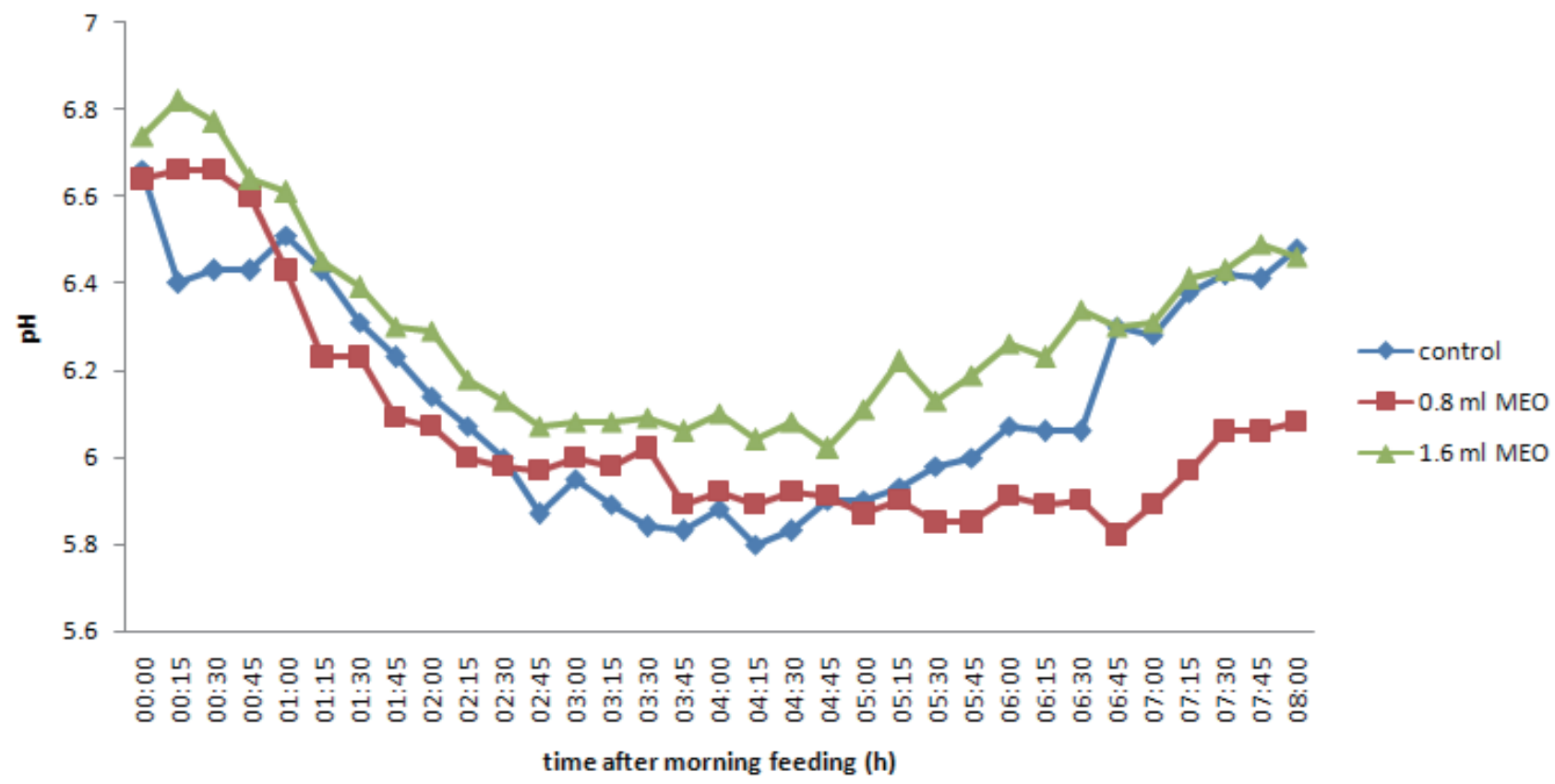

Figure 1. Ruminal pH flactuation during $8 \mathrm{~h}$ after the morning feeding in sheep fed a 50:50 forage:concentrate diet supplemented or not supplemented with a MEO. MEO, mixture of essential oils.

of MEO would be 0.2 and $0.4 \mathrm{~mL} / \mathrm{L}$, respectively, which was higher than other in vivo studies on sheep [38,27,7].

The results of the present study showed that ruminal protozoa and HAP bacteria counts were not affected by addition of MEO in the diet (Table 7). This agreed with Newbold et al [26] and Benchaar et al [6] who reported no effect of CRINA ruminant MEO (110 and 2,000 mg/d, respectively) on total number of protozoa in ruminal fluid of sheep and dairy cattle, respectively. HAP bacteria represent around $1 \%$ of total rumen bacteria, while playing a significant role in ruminal ammonia production [39]. McIntosh et al [4] reported that addition of a blend of EO containing thymol (main active compound of thyme and oregano $\mathrm{EO})$ reduced $(\mathrm{p}<0.05)$ the rate of deamination of amino acid and inhibition of the growth of Clostridium sticklandi and Peptostreptococcus anaerobius, two main species of the HAP bacteria group. Reducing ammonia $\mathrm{N}$ concentration by inhibition of the growth of HAP happened with a mechanism of action similar to that of monensin [40]. The decrease in ruminal ammonia $\mathrm{N}$ concentration with supplementation $1.6 \mathrm{~mL} / \mathrm{d}$ of MEO with no change in HAP bacteria population demonstrated that some obligate amino acid fermenting bacteria that had a high activity for fermentation of amino acids were able to persist in the presence of MEO and increased in relative abundance.

Table 4. Rumen fluid nitrogen fractions ( $\mathrm{mg} / \mathrm{dL}$ ) in sheep fed a 50:50 forage:concentrate diet supplemented or not supplemented with a MEO

\begin{tabular}{|c|c|c|c|c|c|c|c|c|c|}
\hline & \multicolumn{3}{|c|}{ MEO $(\mathrm{mL} / \mathrm{d})$} & \multirow{2}{*}{ SEM } & \multicolumn{3}{|c|}{$\mathrm{p}$-value } & \multicolumn{2}{|c|}{ Contrast } \\
\hline & Control & 0.8 & 1.6 & & Treatment & Period & Treatment×period & Linear & Quadratic \\
\hline \multicolumn{10}{|l|}{ S-Pep+AAN } \\
\hline $2(h)$ & 65.9 & 129.7 & 51.5 & 60.63 & 0.46 & 0.44 & 0.74 & NS & NS \\
\hline $6(h)$ & 72.2 & 92.0 & 116.3 & 15.44 & 0.15 & 0.06 & 0.49 & NS & NS \\
\hline Average & 68.9 & 110.8 & 87.2 & 28.2 & 0.43 & 0.19 & 0.96 & NS & NS \\
\hline \multicolumn{10}{|l|}{ L-PepN } \\
\hline 2 (h) & 10.0 & 6.1 & 13.4 & 9.78 & 0.77 & 0.13 & 0.70 & NS & NS \\
\hline $6(h)$ & 3.5 & 9.7 & 8.3 & 2.75 & 0.2 & 0.02 & 0.24 & NS & NS \\
\hline Average & 6.7 & 7.9 & 10.8 & 5.39 & 0.75 & 0.06 & 0.74 & NS & NS \\
\hline \multicolumn{10}{|l|}{ Ammonia N } \\
\hline $2(h)$ & 15.80 & 17.5 & 14 & 2.61 & 0.67 & - & - & NS & NS \\
\hline 6 (h) & $15.6^{\mathrm{a}}$ & $12.7^{\mathrm{ab}}$ & $7.7^{b}$ & 0.56 & 0.38 & - & - & * & NS \\
\hline Average & 15.7 & 15.2 & 10.9 & 1.41 & 0.43 & - & - & NS & NS \\
\hline
\end{tabular}

MEO, mixture of essential oils (50\% thyme, 30\% cinnamon, and 20\% clove); SEM, standard error of mean; S-Pep+AA N, small peptide plus amino acid nitrogen; NS, non significant; L-Pep N, large peptide nitrogen; -, no stimated; *, significant. 


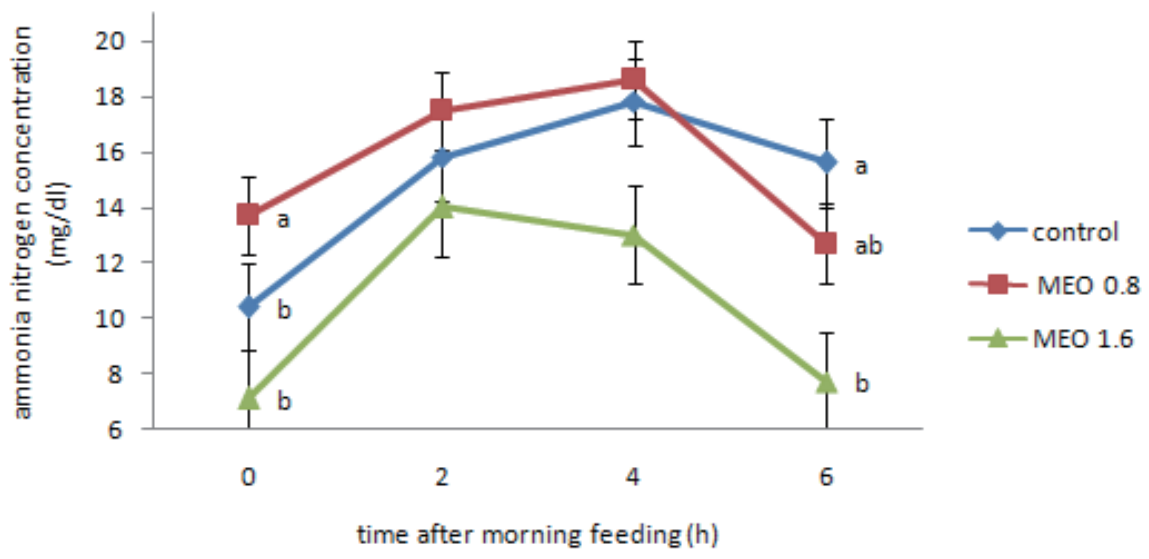

Figure 2. Ruminal ammonia nitrogen fluctuation in sheep fed a 50:50 forage:concentrate diet supplemented or not supplemented with a MEO ( \pm standard error). MEO, mixture of essential oils.

\section{Blood metabolites and cells}

RBC, WBC, and hemoglobin concentration and hematocrit were not affected by MEO supplementation (Table 5). Glucose, BHBA, cholesterol, total protein, albumin and BUN serum concentration were not influenced by the addition of MEO at 0.8 and $1.6 \mathrm{~mL} / \mathrm{head} / \mathrm{d}$ (Table 6). Concentration of AST and ALT enzymes of serum were not affected by MEO addition in the diet. Chaves et al [27] reported that cinnamaldehyde supplementation in lambs did not affect serum glucose and nonesterified fatty acid (NEFA) concentration, although it did result in a decrease in serum cholesterol concentration. Chaves et al
[7] observed that serum NEFA, cholesterol and triglycerides were not affected by cinnamaldehyde supplementation at 100 , 200, and $400 \mathrm{mg} / \mathrm{kg}$ DM. Tassoul and Shaver [41] reported that supplementation of EOM (CRINA) at $1.2 \mathrm{~g} / \mathrm{cow} / \mathrm{d}$ did not have significant effect on plasma NEFA, urea, BHBA and glucose concentration in periparturient and early lactation dairy cows. Serum cholesterol, NEFA and BHBA are indicators of fat mobilization.

Apparent total tract nutrient digestibility Apparent digestibility of DM, CP, OM, and NDF were not in-

Table 5. Blood metabolites of sheep fed a 50:50 forage: concentrate diet supplemented or not supplemented with a MEO

\begin{tabular}{|c|c|c|c|c|c|c|c|c|c|}
\hline \multirow{2}{*}{ Items } & \multicolumn{3}{|c|}{ MEO $(\mathrm{mL} / \mathrm{d})$} & \multirow{2}{*}{ SEM } & \multicolumn{3}{|c|}{$p$-value } & \multicolumn{2}{|c|}{ Contrast } \\
\hline & Control & 0.8 & 1.6 & & Treatment & Period & Treatment×period & Linear & Quadratic \\
\hline Glucose (mg/dL) & 57 & 74.5 & 71 & 16.11 & 0.13 & 0.91 & 0.42 & NS & NS \\
\hline Total protein (g/dL) & 7.37 & 7.36 & 7.12 & 0.16 & 0.05 & 0.15 & 0.26 & NS & NS \\
\hline Albumin (g/dL) & 3.45 & 3.07 & 3.17 & 0.28 & 0.67 & 0.66 & 0.30 & NS & NS \\
\hline BUN (mg/dL) & 20.5 & 21.59 & 19.03 & 2.71 & 0.62 & 0.77 & 0.51 & NS & NS \\
\hline Cholesterol (mg/dL) & 42.75 & 52 & 48.75 & 10.57 & 0.75 & 0.97 & 0.24 & NS & NS \\
\hline $\mathrm{BHBA}(\mathrm{mmol} / \mathrm{L})$ & 0.59 & 0.79 & 0.46 & 0.14 & 0.92 & 0.37 & 0.69 & NS & NS \\
\hline AST (unit/L) & 64.25 & 46.5 & 79.75 & 16.94 & 0.97 & 0.45 & 0.52 & NS & NS \\
\hline ALT (unit/L) & 11.25 & 10 & 12.15 & 2.27 & 0.54 & 0.71 & 0.4 & NS & NS \\
\hline
\end{tabular}

MEO, mixture of essential oils (50\% thyme, 30\% cinnamon and 20\% clove); SEM, standard error of mean; NS, non significant; BUN, blood urea nitrogen; BHBA, $\beta$-hydroxybutyrate; AST, aspartat amino transferase; ALT, alanine amino transferase.

Table 6. Blood cells concentration of sheep fed a 50:50 forage:concentrate diet supplemented or not supplemented with a MEO

\begin{tabular}{|c|c|c|c|c|c|c|c|c|c|}
\hline \multirow{2}{*}{ Items } & \multicolumn{3}{|c|}{ MEO $(\mathrm{mL} / \mathrm{d})$} & \multirow{2}{*}{ SEM } & \multicolumn{3}{|c|}{ Contrast } & \multicolumn{2}{|c|}{$\mathrm{p}$-value } \\
\hline & Control & 0.8 & 1.6 & & Treatment & Period & Treatmentxperiod & Linear & Quadratic \\
\hline $\mathrm{RBC}\left(\times 10^{6} / \mu \mathrm{L}\right)$ & 9.25 & 8.7 & 7.72 & 1.61 & 0.07 & 0.73 & 0.26 & NS & NS \\
\hline WBC $\left(\times 10^{3} / \mu \mathrm{L}\right)$ & 7.43 & 6.88 & 7.97 & 0.9 & 0.18 & 0.73 & 0.85 & NS & NS \\
\hline $\mathrm{HGB}(\mathrm{g} / \mathrm{dL})$ & 10.7 & 8.78 & 8.9 & 0.98 & 0.41 & 0.43 & 0.53 & NS & NS \\
\hline Hematocrit (\%) & 61.81 & 33.83 & 37.04 & 10.44 & 0.2 & 0.27 & 0.28 & * & NS \\
\hline
\end{tabular}

MEO, mixture of essential oils (50\% thyme, $30 \%$ cinnamon, and $20 \%$ clove); SEM, standard error of mean; RBC, red blood cells; NS, non significant; WBC, White blood cells; HGB, hemoglobin; * significant. 
Table 7. Nutrient apparent digestibility and rumen protozoa and HAP bacteria counts in sheep fed a 50:50 forage:concentrate diet supplemented or not supplemented with a MEO

\begin{tabular}{|c|c|c|c|c|c|c|c|c|c|}
\hline \multirow{2}{*}{ Items } & \multicolumn{3}{|c|}{ MEO (mL/d) } & \multirow{2}{*}{ SEM } & \multicolumn{3}{|c|}{$p$-value } & \multicolumn{2}{|c|}{ Contrast } \\
\hline & Control & 0.8 & 1.6 & & Treatment & Period & Treatmentxperiod & Linear & Quadratic \\
\hline \multicolumn{10}{|l|}{ Digestibility (g/kg) } \\
\hline DM & 799 & 774 & 767 & 42.78 & 0.40 & 0.22 & 0.66 & NS & NS \\
\hline $\mathrm{CP}$ & 744 & 602 & 588 & 62.07 & 0.17 & 0.11 & 0.4 & NS & NS \\
\hline OM & 740 & 587.5 & 604.4 & 71.21 & 0.2 & 0.03 & 0.10 & NS & NS \\
\hline NDF & 599 & 477 & 484 & 64.61 & 0.14 & 0.30 & 0.31 & NS & NS \\
\hline HAP Bacteria $(\log 10)$ & 6.92 & 7.58 & 7.23 & 0.360 & 0.29 & - & - & NS & NS \\
\hline Protozoa $\left(\times 10^{4} / \mathrm{mL}\right)$ & 45.33 & 32.87 & 39.66 & 0.79 & 0.30 & 0.49 & 0.78 & NS & NS \\
\hline
\end{tabular}

HAP, hyper ammonia producing; MEO, mixture of essential oils (50\% thyme, 30\% cinnamon, and $20 \%$ clove); SEM, standard error of mean; DM, dry matter; NS, non significant; CP, crude protein; OM, organic matter; NDF, neutral detergent fiber; -, no stimated.

fluenced by MEO supplementation (Table 7), which agree with findings of Benchaar et al [6], who reported no change in total tract apparent digestibility of DM, CP, and NDF in dairy cows consuming a diet supplemented with $2 \mathrm{~g} / \mathrm{d}$ of a MEO (CRINA ruminants). Tager and Krause [29] reported a decrease in $24 \mathrm{~h}$ in situ NDF, ADF, and OM disappearance in dairy cows when supplemented with $10 \mathrm{~g} / \mathrm{d}$ of a mixture of EO compounds contained 1,700 mg cinnamaldehyde and 2,800 mg eugenol, while no effect was observed on total tract apparent digestibility of DM, OM, CP, NDF, and ADF. Castillejos et al [30] reported that supplementation thymol at $500 \mathrm{mg} / \mathrm{L}$ in a dual-flow continuous culture system resulted in a decrease in DM digestibility relative to the control. In addition, DM and CP disappearance decreased with supplementation $1 \mu \mathrm{L} / \mathrm{mL}$ of thyme, cinnamon and clove EO [14] or $280 \mu \mathrm{L} / \mathrm{L}$ of thyme and cinnamon EO [35] in a 24 $\mathrm{h}$ batch culture system. However, reduction in nutrients digestibility would be unfavorable for ruminants. Discrepancy between studies results could be due to experimental conditions (in vitro vs in vivo, ruminal evaluation vs total tract evaluation), dose of supplementation and kind of EO or it compounds. Total tract digestibility of nutrients were not affected by EO supplementation compared with in sacco and $24 \mathrm{~h}$ in vitro studies, suggesting that decrease of ruminal digestion could be compensated at post-ruminal sites. In addition, longer exposure time of ruminal microorganisms (in vivo and long time in vitro continuous culture vs short time batch culture study) to EO may allow rumen microbiota to adapt to the $\mathrm{EO}[33,34]$.

\section{CONCLUSION}

It can be concluded that the supplementation of MEO used in the present study up to $1.6 \mathrm{~mL} / \mathrm{d}$ did not change ruminal microbial fermentation characteristics (except for ammonia $\mathrm{N}$ concentration), rumen microbial counts, blood chemical metabolites and cells, and apparent total tract nutrients digestibility in sheep fed with a 50:50 forage:concentrate diet. The results of the current study suggested that future studies should focus on the investigation of doses higher than $1.6 \mathrm{~mL} / \mathrm{d}$ of MEO.

\section{CONFLICT OF INTEREST}

We certify that there is no conflict of interest with any financial organization regarding the material discussed in the manuscript.

\section{ACKNOWLEDGMENTS}

Funding for this research was provided by University of Kurdistan. The authors would like to thank vice-chancellor of research of University of Kurdistan.

\section{REFERENCES}

1. European Commission. Regulation (EC) no. 1831/2003 of the European Parliament and of the Council of 22 September 2003 on additives for use in animal nutrition. Official J European Union 2003;268:29-43.

2. Dorman HJD, Deans SG. Antimicrobial agents from plants: antibacterial activity of plant volatile oils. J Appl Microbiol 2000;88: 308-16.

3. Burt S. Essential oils: their antibacterial properties and potential applications in foods-A review. Int J Food Microbiol 2004;94: 223-53.

4. McIntosh FM, Williams P, Losa R, et al. Effects of essential oils on ruminal microorganisms and their protein metabolism. Appl Environ Microbiol 2003;69:5011-4.

5. Chao SC, Young DG, Oberg CJ. Screening for inhibitory activity of essential oils on selected bacteria, fungi and viruses. J Essent Oil Res 2000;12:639-49.

6. Benchaar C, Petit HV, Berthiaume R, Whyte TD, Chouinard PY. Effects of addition of essential oils and monensin premix on digestion, ruminal fermentation, Milk production, and Milk composition in dairy cows. J Dairy Sci 2006;89:4352-64.

7. Chaves AV, Dugan MER, Stanford K, et al. A dose-response of cinnamaldehyde supplementation on intake, ruminal fermentation, blood metabolites, growth performance, and carcass characteristics of growing lambs. Livest Sci 2011;141:213-20.

8. Giannenas I, Skoufos J, Giannakopoulos C, et al. Effects of essential oils on milk production, milk composition, and rumen microbiota 
in Chios dairy ewes. J Dairy Sci 2011;94:5569-77.

9. Bode HB, Muller R. Possibility of bacterial recruitment of plant genes associated with the biosynthesis of secondary metabolites. Plant Physiol 2003;132:1153-61.

10. Busquet M, Calsamiglia S, Ferret A, Kamel C. Plant extracts affect in vitro rumen microbial fermentation. J Dairy Sci 2006;89:76171.

11. Benchaar C, Chaves AV, Fraser GR, et al. Effects of essential oils and their components on in vitro rumen microbial fermentation. Can J Anim Sci 2007;87:413-9.

12. Castillejos L, Calsamiglia S, Martín-Tereso J, Ter Wijlen H. In vitro evaluation of effects of ten essential oils at three doses on ruminal fermentation of high concentrate feedlot-type diets. Anim Feed Sci Technol 2008;145:259-70.

13. Yang WZ, Ametaj BN, Benchaar C, He ML, Beauchemin KA. Cinnamaldehyde in feedlot cattle diets: intake, growth performance, carcass characteristics, and blood metabolites. J Anim Sci 2010;88: 1082-92.

14. Jahani-Azizabadi H, Danesh Mesgaran M, Vakili AR, Rezayazdi $\mathrm{K}$, Hashemi M. Effect of various semi-arid native medicinal plant essential oils on rumen fermentation characteristics of a high forage diet using. Afr J Microbiol Res 2011; 27:4812-9.

15. Dehority BA. Evaluation of subsampling and fixation procedures used for counting rumen protozoa. Appl Environ Microbiol 1984; 48:182-5.

16. Caldwell DR, Bryant MP. Medium without rumen fluid for nonselective enumeration and isolation of rumen bacteria. Appl Environ Microbiol 1966;14:794-801.

17. Chen G, Russell JB. Fermentation of peptides and amino acids by a monensin-sensitive ruminal peptostreptococcus. Appl Environ Microbiol 1988;54:2742-9.

18. Chen G, Russell JB. More monensin-sensitive, ammonia-producing bacteria from the rumen. Appl Environ Microbiol 1989;55:1052-7.

19. AOAC (Association of Official Analytical Chemists) International. Official Methods of Analysis. 15th edn. Arlington, VA: AOAC International; 1990

20. Winter KA, Johnson RR, Dehority BA. Metabolism of urea nitrogen by mixed cultures of rumen bacteria grown on cellulose. J Anim Sci 1964;47:793-7.

21. Licitra G, Hernandez TM, Van Soest PJ. Standardization of procedures for nitrogen fractionation of ruminant feeds. Anim Feed Sci Technol 1996;57:347-58.

22. Van Soest PV, Robertson JB, Lewis BA. Methods for dietary fiber, neutral detergent fiber, and nonstarch polysaccharides in relation to animal nutrition. J Dairy Sci 1991;74:3583-97.

23. Jouany JP. Volatile fatty acids and alcohol determination in digestive contents, silage juices, bacterial cultures and anaerobic fermentor contents. Sci Aliments 1982; 2:131-44.

24. Demeyer D, Van Nevel CJ. Methanogenesis, an integrated part of carbohydrate fermentation and its control. In: McDonald LW, Warner ACI, editors. Digestion and metabolism in the ruminant. Armidale, Australia: University of New England Publishing Unit.; 1975. pp.
366-82.

25. SAS. Statistical Analysis Systems User's Guide. Version 8.2. Cary, NC: SAS Institute, Inc; 1999.

26. Newbold CJ, McIntosh FM, Williams P, Losa R, Wallace RL. Effects of a specific blend of essential oil compounds on rumen fermentation. Anim Feed Sci Technol 2004;114:105-12.

27. Chaves AV, Stanford K, Dugan MER, et al. Effects of cinnamaldehyde, garlic and juniper berry essential oils on rumen fermentation, blood metabolites, growth performance, and carcass characteristics of growing lambs. Livest Sci 2008;17:215-24.

28. Benchaar C, Calsamiglia S, Chaves AV, et al. A review of plant-derived essential oils in ruminant nutrition and production. Anim Feed Sci Technol 2008;145:209-28.

29. Tager LR, Krause KM. Effects of essential oils on rumen fermentation, milk production, and feeding behavior in lactating dairy cows. J Dairy Sci 2011;94:2455-64.

30. Castillejos L, Calsamiglia S, Ferret A. Effect of essential oil active compounds on rumen microbial fermentation and nutrient flow in in vitro systems. J Dairy Sci 2006;89:2649-58.

31. Agarwal N, Shekhar C, Kumar R, Chaudhary LC, Kamra DN. Effect of peppermint (Mentha piperita) oil on in vitro methanogenesis and fermentation of feed with buffalo rumen liquor. Anim Feed Sci Technol 2009;148:321-7.

32. Benchaar C, Greathead H. Essential oils and opportunities to mitigate enteric methane emissions from ruminants. Anim Feed Sci Technol 2011;166:338-55.

33. Cardozo PW, Calsamiglia S, Ferret A, Kamel C. Effects of natural plant extracts on ruminal protein degradation and fermentation profiles in continuous culture. J Anim Sci 2004;82:3230-6.

34. Busquet M, Calsamiglia S, Ferret A, Cardozo PW, Kamel C. Effects of cinnamaldehyde and garlic oil on rumen microbial fermentation in a dual flow continuous culture. J Dairy Sci 2005;88:2508-16.

35. Jahani-Azizabadi H, Danesh Mesgaran M, Vakili AR, Rezayazdi $\mathrm{K}$. Effect of some plant essential oils on in vitro ruminal methane production and on fermentation characteristics of a mid-forage diet. J Agric Sci Technol 2014; 16:1543-54.

36. Benchaar, C, McAllister TA, Chouinard PY. Digestion, ruminal fermentation, ciliate protozoal populations, and milk production from dairy cows fed cinnamaldehyde, quebracho condensed tannin, or Yucca schidigera saponin extracts. J Dairy Sci 2008; 91:4765-77.

37. Yang WZ, Ametaj BN, Benchaar C, Beauchemin KA. Dose response to cinnamaldehyde supplementation in growing beef heifers: ruminal and intestinal digestion. J Anim Sci 2010;88:680-8.

38. Chaves AV, Stanford K, Gibson LL, McAllister TA, Benchaar C. Effects of carvacrol and cinnamaldehyde on intake, rumen fermentation, growth performance, and carcass characteristics of growing lambs. Anim Feed Sci Technol 2008;145:396-408

39. Russell JB, Onodera R, Hino T. Ruminal protein fermentation: new perspectives on previous contradictions. In: Tsuda T, Sasaki Y, Kawashima R, editors. Physiological aspects of digestion, metabolism in ruminants: proceedings of the seventh international symposium on ruminant physiology. London, UK: Academic 
Press; 1991. pp. 681-97.

40. Russell JB, Strobel HJ. Effects of additives on in vitro ruminal fermentation: A comparison of monensin and bacitracin, another gram-positive antibiotic. J Anim Sci 1988;66:552-8.
41. Tassoul MD, Shaver RD. Effect of a mixture of supplemental dietary plant essential oils on performance of periparturient and early lactation dairy cows. J Dairy Sci 2009;92:1734-40. 